\title{
IDENTIFICATION OF TWO SPECIES OF F usarium Link THAT CAUSE WILTING OF COLORED CALLAS (Zantedeschia aethiopica (L.) Spreng.) CULTIVATED UNDER GREENHOUSE CONDITIONS IN CHILE
}

\author{
Luigi Ciampi P. ${ }^{*}$, Juan Nissen M. ${ }^{1}$, Elizabeth Venegas G. ${ }^{1}$, Ricardo Fuentes P. ${ }^{1}$, Marcia Costa L. ${ }^{1}$, \\ Renate Schöbitz T. ${ }^{1}$, Eduardo Alvarez D. ${ }^{1}$, and Pilar Alvarado A. ${ }^{1}$
}

\begin{abstract}
Calla (Zantedeschia aethiopica (L.) Spreng.) is a flower that is conquering international markets. It is very important to maintain the healthiness of the crop during its development in order to obtain high quality plants that meet the demands of the markets. The objective of this investigation was to determine the etiological agent(s) of a pathology never observed before in Chile that causes vascular wilt during the cultivation of colored calla developed under greenhouse conditions. Fungal isolates were collected from infected plants. Pathogenicity tests, microscopic observations, and scanning electronic microscopy evaluations were also conducted. Healthy calla tubers were inoculated with isolates of the genus Fusarium Link. Plants grown during 5 months in a climatic chamber showed five classes of symptoms: damping off, dwarfism, intense wilting, mild wilting and no symptoms. The isolates were identified at the species level and it was found that $20 \%$ was Fusarium solani (Mart.) Sacc. and $80 \%$ was Fusarium oxysporum Schltdl. Results and collected evidence these two new species that affect production of calla under greenhouse conditions in Chile.
\end{abstract}

Key words: Fusarium solani, Fusarium oxysporum, colored calla, Zantedeschia aethiopica.

\section{INTRODUCTION}

The calla lily (Zantedeschia aethiopica (L.) Spreng.) is a relatively new product in the Chilean productive sector. Demand for the product is increasingly globally, with the highest demand centered in the Northern Hemisphere (Salinger, 1994).

The optimal productive conditions for the calla lily in greenhouses can also favor the development of various phytopathogenic agents that can cause harm to hosts, affecting development, quality and yield (Hertogh and Le Nard, 1993; Jacobs, 1997).

According to Hertogh and Le Nard (1993), one of the most important phytopathogenes of the calla is the bacteria Erwinia carotovora (Jones) Bergey, which causes wet rot in the tubers and stalks of the plant. Likewise, problems with roots are commonly provoked by fungi of the genera Phytophthora de Bary, Pythium Pringsh.

${ }^{1}$ Universidad Austral de Chile, Facultad de Ciencias Agrarias, Casilla 567, Valdivia, Chile. "Corresponding author (lciampi@uach.cl).

Note: Part of results was informed in Congress of Sociedad Chilena de Fitopatología XIV SOCHIFIT, Talca, Chile, 3 December 2004.

Received: 06 August 2008.

Accepted: 10 December 2008. and Rhizoctonia D.C. The genus Penicillium Link is recognized as an important cause of tuber rot in storage, while Phytophthora spp, and Xanthomonas campestris (Pamm.) Dow are harmful to the aerial part of the plant. Finally, Alternaria Nees ex Fr. is reported as a harmful fungus to postharvest flowers. In a study by Wright (1998) in New Zealand, four pathogenic agents were isolated that cause major damage to calla crops: Fusarium solani (Mart.) Sacc., Rhizoctonia spp., Pythium spp. and E. carotovora subsp. carotovora (Jones) Bergey. While F. solani was characterized as an important pathogen, the major damage in plants was produced by E.c. subsp. carotovora. There is little information in general about the problems that cause the genus Fusarium Link in calla plants in Chile. According to Kunstmann (2004), there are not many phytosanitary problems in Chile that affect colored callas, or the problems are unknown. We note the complex of bacteria of the Erwinia group, with two sub-species carotovora and atroseptica (van Hall) Dye, as causal agents of serious problems to productive units in the country. Other agents that affect the cultivar are unknown.

The objective of this research was to establish the genus and species of the etiological agent(s) responsible for inducing severe vascular wilt in colored calla plants 
grown under greenhouse conditions in Los Ríos Region of Chile.

\section{MATERIALS AND METHODS}

\section{Obtaining samples}

This work was carried out in 2004 in the Phytopathology Laboratory of the Faculty of Agricultural Sciences, Institute of Vegetal Production and Health, Universidad Austral de Chile, Valdivia, Chile. The material used for phytopathogenic diagnosis was obtained from a greenhouse in Cayumapu, $30 \mathrm{~km}$ north of the city of Valdivia. Thirty-five plants were collected that presented strong symptoms of wilt, with clear signs of whitening of their tubers. The collection took place on 25 March 2004. At that time of year the cultivar was being developed in greenhouse.

\section{Pure cultures}

To obtain fungal cultures, plants were selected that showed symptoms of wilting and whose tubers evidenced signs of whitening on the surface. Potato dextrose agar (PDA) was used as culture medium for the isolates (Dhingra and Sinclair, 2000). For this effect, mother tubers of cv. Treasure were used, with development of daughter tubers and roots of calla plants evidently affected by vascular wilt. The isolation method involved taking four inoculum from whitish fungal structures present on affected parts of the plants and depositing them, using a sterile inoculating loop, on Petri dishes with PDA (Tuite, 1969). The Petri dishes were incubated in an oven for one week at $25{ }^{\circ} \mathrm{C}$. The initial isolates were purified in PDA until pure cultures were obtained. As well, the conidia seeding technique was used for the isolation of fungi of the genus, Fusarium spp., as described by Armentrout (1988).

\section{Identification of genera}

All of the fungal isolates were classified to the genus level by means of taxonomic keys. This process was carried out according to the macroscopic characteristics of the colony, as well as microscopic structures (Von Arx, 1981). A collection was developed with all the cultures corresponding to the genus Fusarium spp., which was used to identify strains at the species level and to prepare samples for the scanning electronic microscope (SEM). Each isolate was seeded in tubers inclined in PDA, with three replicates of each strain. The tubers were incubated for five days at $25^{\circ} \mathrm{C}$ to develop the fungi. They were then refrigerator stored $4{ }^{\circ} \mathrm{C}$.

\section{Pathogenicity test}

Koch's postulates were applied to associate the causal agent of the pathology developed. Successive stages were carried out to inoculate the 60 strains of Fusarium spp. in Armstrong agar, in accordance with the methodology of Armstrong and Armstrong (1975). In this process, 189 healthy calla lily tubers (var. Florex Gold) of the same caliber were inoculated. The tubers had been obtained by micro in vitro propagation, which assured the healthiness of the propagule. The pathogenicity test consisted of depositing Fusarium strains in cavities made in agar that were then covered with sterile solid vaseline. Three controls were used, each with three replicates: disinfected tubers, disinfected tubers, each with a perforation covered with sterile solid vaseline, and disinfected tubers, each with a perforation to introduce a disk of sterile Armstrong agar covered with sterile solid vaseline. The pots, containing tindalized soil, were located randomly in a climatic chamber regulated at a photoperiod of $16: 8 \mathrm{~h}$ and a temperature between 22 and $25^{\circ} \mathrm{C}$, respectively. During the five months of the assay, the plants were watered every two days with $100 \mathrm{~mL}$ of distilled sterile water and once a week with $100 \mathrm{~mL}$ of nutritive solution during the first month. The plants were observed every 7 days during their development and the following parameters were recorded: date of seedling emergence, failure of emergence, average height of each plant (from the base of the stalks to the base of their respective leaves), number of stalks per plant, average diameter of stalks of each plant, and date that symptomology began. At the end of the assay, the parameters of height and number and diameter of stalks were recorded again and the plants were grouped according to the symptoms that had developed.

\section{Species identification}

The identification of Fusarium species was carried out at the Mycology Laboratory of the Universidad de Valparaíso, under the direction of the mycologist Dr. Eduardo Piontelli. Cultures of each example were seeded by the macroconidia generation method, the macroconidia induced on carnation agar (sterile carnation leaves on water agar). Some of the strains were submitted to observation with SEM, according to the protocol used at the Microscopy Laboratory of the Embryology Institute of the Science Faculty, Universidad Austral de Chile (Garrido, O., 2005. Universidad Austral de Chile. Personal communication).

The species identified in this stage of the research were cultivated in soil agar (Dhingra and Sinclair, 2000) on slides with the aim of having the fungi develop adhering to the slides, which would make their subsequent handling and observation easier. In order to fix all the samples at the time, the fungi were cultured with different dates. The chlamydospores lasted for 14 days, the macroconidias for 7 days and the phyalides and microconidias for 4 days. 
Finally the samples were observed with the scanning electronic microscope (LEO 420, Carl Zeiss SMT, Oberkochen, Germany) and photographs were obtained of the characteristic structures of the identified species. No statistical analysis was applied given the nature of the study.

\section{RESULTS AND DISCUSSION}

The relative humidity in the greenhouses during the sampling was in the range of 70 to $85 \%$, the daily temperature was between 23 and $25^{\circ} \mathrm{C}$ and the nocturnal temperature was between 17 and $20^{\circ} \mathrm{C}$. Figure 1 shows normal plants (A) and others with problems of vascular wilt with secondary symptoms (B). The secondary symptoms were marked dwarfism of plants, which exhibited curling and death of the most affected leaves. The leaves were brown, wrinkled and dried out. The tubers of these plants had symptoms of dry rot and clear and visible symptoms of sporodochia (Figure 2-A). Some roots showed signs of whitening mycelium (Figure 2-B).

This description concurs with those of many authors on the effects and pathologies caused by fungal agents associated with the genus Fusarium present in tubers (Cook and Baker, 1989; Agrios, 1997). No bacteria were detected during the isolation process of the genus Erwinia, which commonly causes wet rot in tubers (Kunstmann, 2004). No evidence of other phytopathogenes was found during this procedure.

\section{Classification of fungal isolates}

Seven fungal genera (Table 1) were isolated from the 35 tubers collected from greenhouse plants with symptoms of wilt. Among the isolates, Fusarium spp. had an occurrence of $64.6 \%$, Gliocladium spp. 56.9\%, and Penicillium spp. $44.3 \%$. The latter appeared in the most deteriorated samples. Trichoderma spp. was present in $5.1 \%$ and the rest of the fungi did not exceed $1.3 \%$. In general, the presence of these fungal geneses was greater in the mother tubers, lower in roots and low in daughter tubers. While Fusarium spp. and Gliocladium spp. presented $82.7 \%$ in the mother tubers, only Fusarium spp. led in presence in daughter tubers and roots, with 33.3 and $68.9 \%$, respectively. As well, Gliocladium spp. was present in the same structures at 23.8 and $55.2 \%$, respectively, and Penicillium spp. 58,6\% in the mother tubers, and $23.8 \%$ and $48.2 \%$ in daughter tubers and roots, respectively. Geotrichum spp. showed the same tendency of the aforementioned fungi, while Trichoderma spp. and Cladosporium spp. presented a higher incidence in the roots than in the other structures.

Of the seven fungal isolates, it was established that only Fusarium spp. has pathogenic activity that is known at a world level and that affects many cultivars in Chile (Ciampi et al., 2006). It also had a major presence in all of the samples of the other fungi. Nevertheless, it presented the same incidence in the mother tubers as Gliocladium spp. While the latter did not present information or scientific evidence of pathogenic activity for cultivars, pathogenicity was not evaluated in this study. Strains of this species have been reported in the literature as a biological controller of Septoria spp. and Fusarium spp. Nevertheless, this information does not demonstrate the probability that Gliocladium spp. is responsible for the

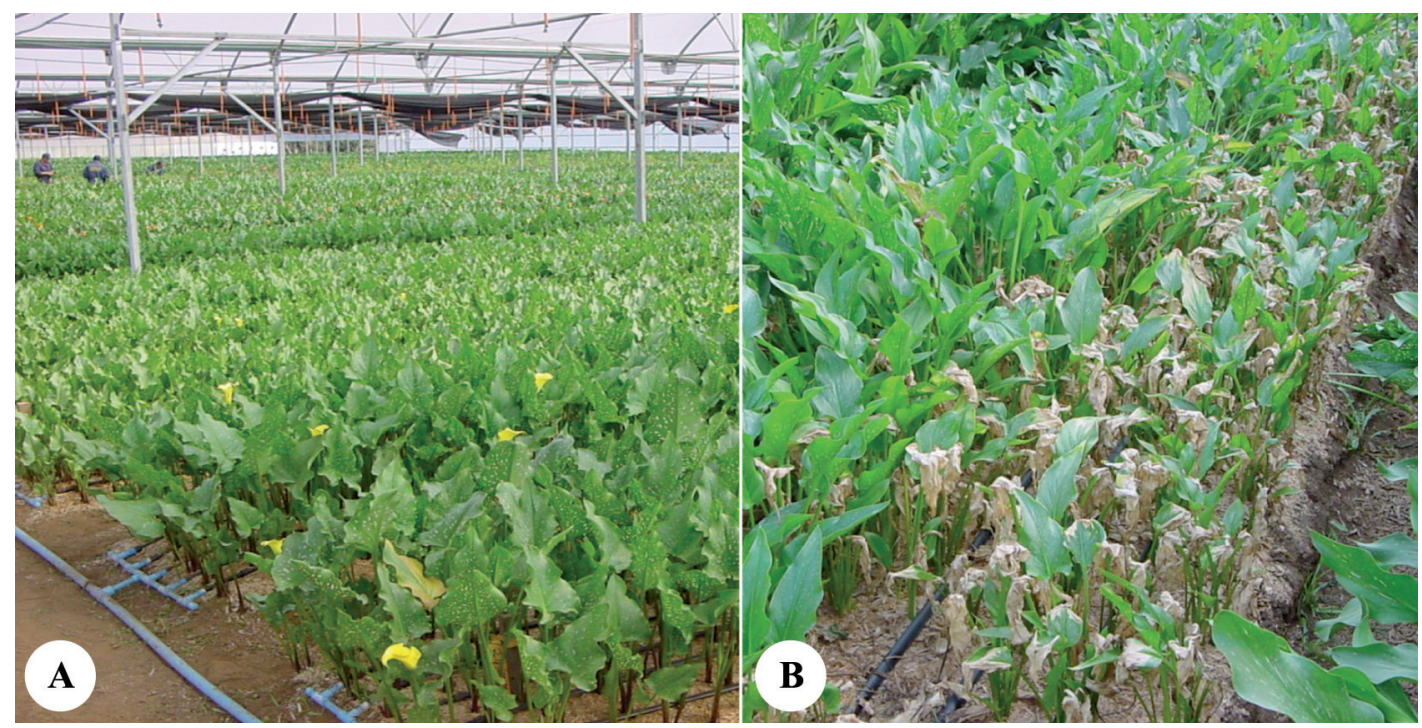

Figure 1. Calla cultivation under greenhouse conditions. (A) General view of healthy plants. (B) Plants with vascular wilt symptoms. 

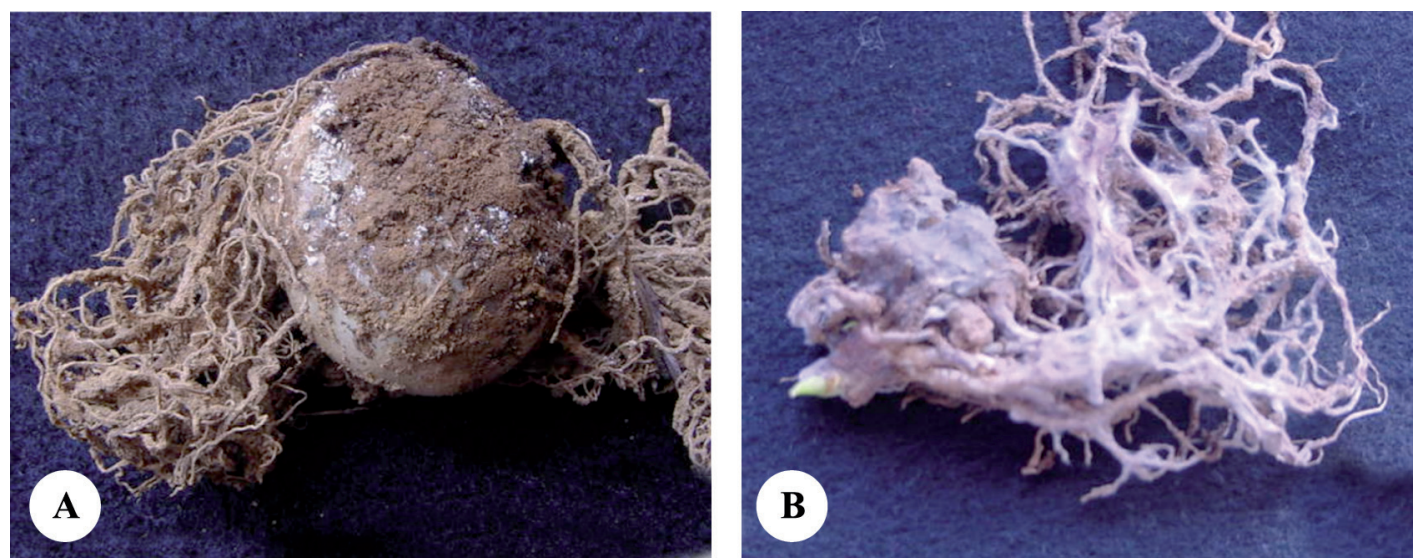

Figure 2. (A) Sporodochia on tubers. (B) White mycelium on roots (without magnification).

Table 1. Genera of fungi isolated from calla tubers with vascular wilt symptoms and their presence in mother and daughter tubers and roots.

\begin{tabular}{|c|c|c|c|c|c|c|c|c|}
\hline \multirow[b]{2}{*}{ Genus } & \multicolumn{4}{|c|}{ Number of organs } & \multicolumn{4}{|c|}{ Fungi per structure } \\
\hline & mt & dt & $\mathbf{r}$ & Total & mt & dt & $\mathbf{r}$ & Total \\
\hline Fusarium & 24 & 7 & 20 & 51 & 82.7 & 33.3 & 68.9 & 64.6 \\
\hline Gliocladium & 24 & 5 & 16 & 45 & 82.7 & 23.8 & 55.2 & 56.9 \\
\hline Penicillium & 17 & 5 & 14 & 35 & 58.6 & 23.8 & 48.2 & 44.3 \\
\hline Trichoderma & 1 & 1 & 2 & 4 & 3.5 & 4.8 & 6.9 & 5.1 \\
\hline Trichotecium & 0 & 0 & 1 & 1 & 0 & 0 & 3.5 & 1.3 \\
\hline Cladosporium & 0 & 0 & 1 & 1 & 0 & 0 & 3.5 & 1.3 \\
\hline Geotrichum & 1 & 0 & 0 & 1 & 3.5 & 0 & 0 & 1.3 \\
\hline Total & 29 & 21 & 29 & 79 & 100 & 100 & 100 & 100 \\
\hline
\end{tabular}

$\mathrm{mt}$ : mother tuber; dt: daughter tuber; r: roots.

symptoms in the callas plants. In this respect, only $G$. aureum has been reported as a causal agent of hard rot in carrots (Daucus carota L.) (Snowdon, 1991), and is not reported in the literature as a cause of vascular problems in calla. Tests were not made using other genera because they were not considered of interest for the study.

It is interesting to note that Penicillium spp. has been reported as a phytopathogen of callas during postharvest (Hertogh and Le Nard, 1993). On the other hand, according to Cook (1993) and Alexopoulos et al. (1996), the genera Trichotecium and Trichoderma include species that are known for their antagonic capacity to phytopathogenic fungus. Cladosporium spp. and Geotrichum spp. have been reported as pathogens in determined occasions. However, given their low number and scarce presence, they are ruled out as responsible for the observed symptoms of vascular wilt.

\section{Classification of F usarium spp. isolates}

Sixty isolates of Fusarium spp. were obtained from the tubers of plants with symptoms of vascular wilt. This first approximation of the isolates to this genus concurs with the characteristics described by Snyder and Hansen (1940), cited by Nelson et al. (1994). These authors indicate that the system of taxonomy is mainly based on the analysis of cultures developed from the seeding of only one conidia of Fusarium spp., the procedure used in this work. The authors also indicate that this process allows for obtaining fewer variations of the macroconidias. Not using this method of isolation results in generating wide variability in conidial length, width and the number of septa. As well, the intensity of the pigments produced is highly variable, making it difficult to classify the species of the genera.

\section{Pathogenicity tests}

During the assay the inoculated plants developed symptoms of different intensities: seedling damping off, dwarfism, intense vascular wilt, mild vascular wilt and plants without symptoms (Figure 3). At the end of 

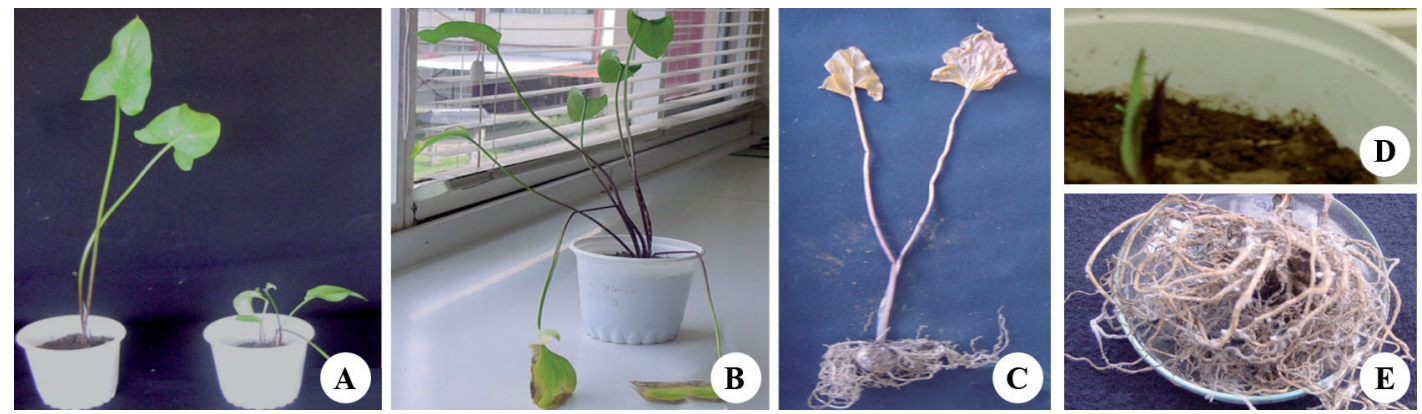

A) Plant without symtoms (left), plant with dwarfism (right). B) Plant with mild vascular wilt. C) Plant with intense vascular wilt. E) Roots with sporodochia of Fusarium Link.

Figure 3. Symptoms observed on calla plants inoculated with F usarium spp. isolates.

this stage, the 60 isolates were grouped to facilitate identification. This process was done taking into consideration that sections are divided into species, varieties and special forms, in accordance with Nelson et al. (1994). As well, growth velocity and the presence or absence of odors was considered. The type of
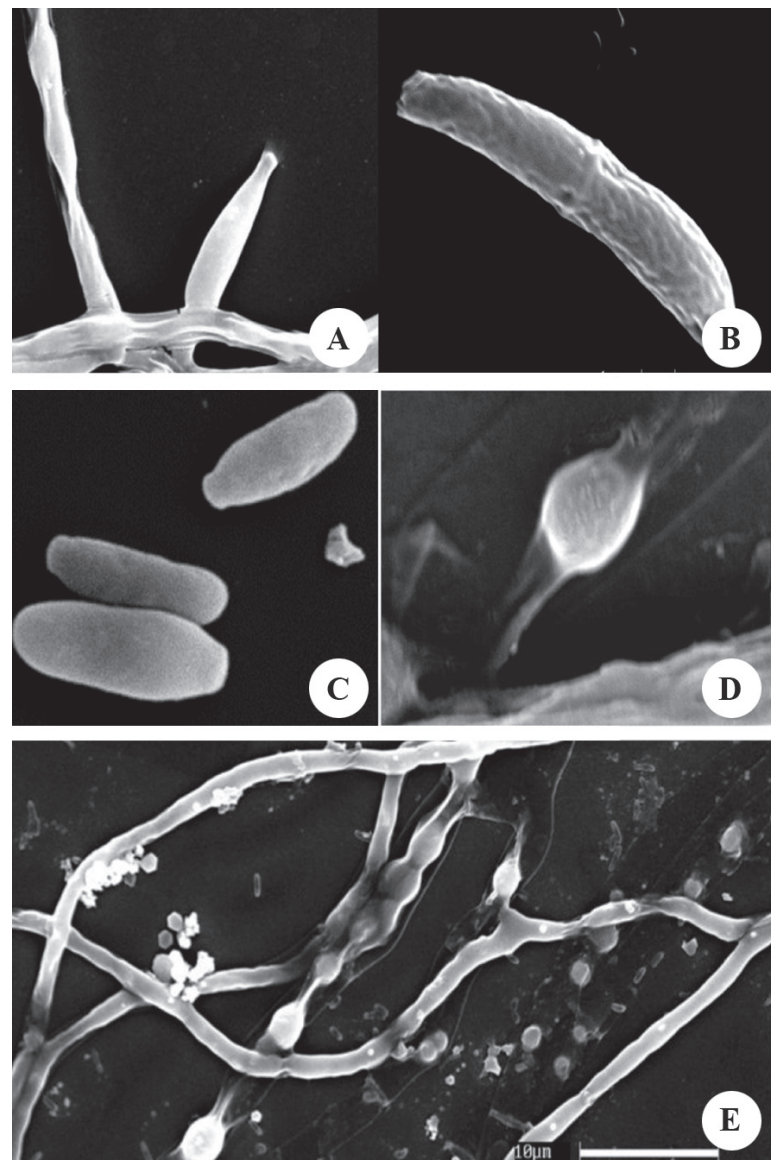

Figure 4. Scanning electron microscopy of ultrastructures of Fusarium oxysporum. (A) Phyalide (3700X); (B) Macroconidium (2500X); (C) Microconidia (4000X); (D) Chlamydospore (5000X); (E) Chlamydospore (2600X). phyalides and number of septa in the macroconidias were considered in the microscopic observations of the fungi. Ten groups Fusarium spp. were obtained from this process. An example of each group was taken to the mycology laboratory of the Universidad de Valparaíso for taxonomical classification at the species level. Following identification and pathogenicity tests, distinct groups were established according to the aggressiveness of the Fusarium spp. strains.

\section{Identification of Fusarium species}

The ten isolates of Fusarium spp. representative of each group that had been submitted to the identification process were seeded using the method of a spore in carnation leaf agar and in PDA. The characteristics of the colonies on these substrates were evaluated and their structures were measured (Table 2). Two species were identified: $20 \%$ of the isolates corresponding to F. solani and $80 \%$ to F. oxysporum.

According to Booth (1975), the determined species are closely related, given that they shared morphological characteristics. However, they have small differences, for example, the microconidias of $F$. solani do not have septa and originate from long conidiophores, while those of $F$. oxysporum have one or two septa and originate form short conidiophores. To make a good determination of the ultramicroscopic characteristics of Fusarium spp., the isolates were cultured on soil agar (Figures 4 and 5). This procedure is recommended by Klotz et al. (1988), as cited by Nelson et al. (1994). The structures had relatively optimal and stable growth in this media. The evaluated isolations produced all their structures: phyalides, chlamydospores, macroconidias and microconidias, facilitating taxonomic classification at the species level.

\section{Capacity of F usarium species to harm inoculated calla plants}

The evaluations of the 60 isolates of Fusarium spp. provided expected results. The three controls did not develop symptoms or signs in the inoculated plants. 

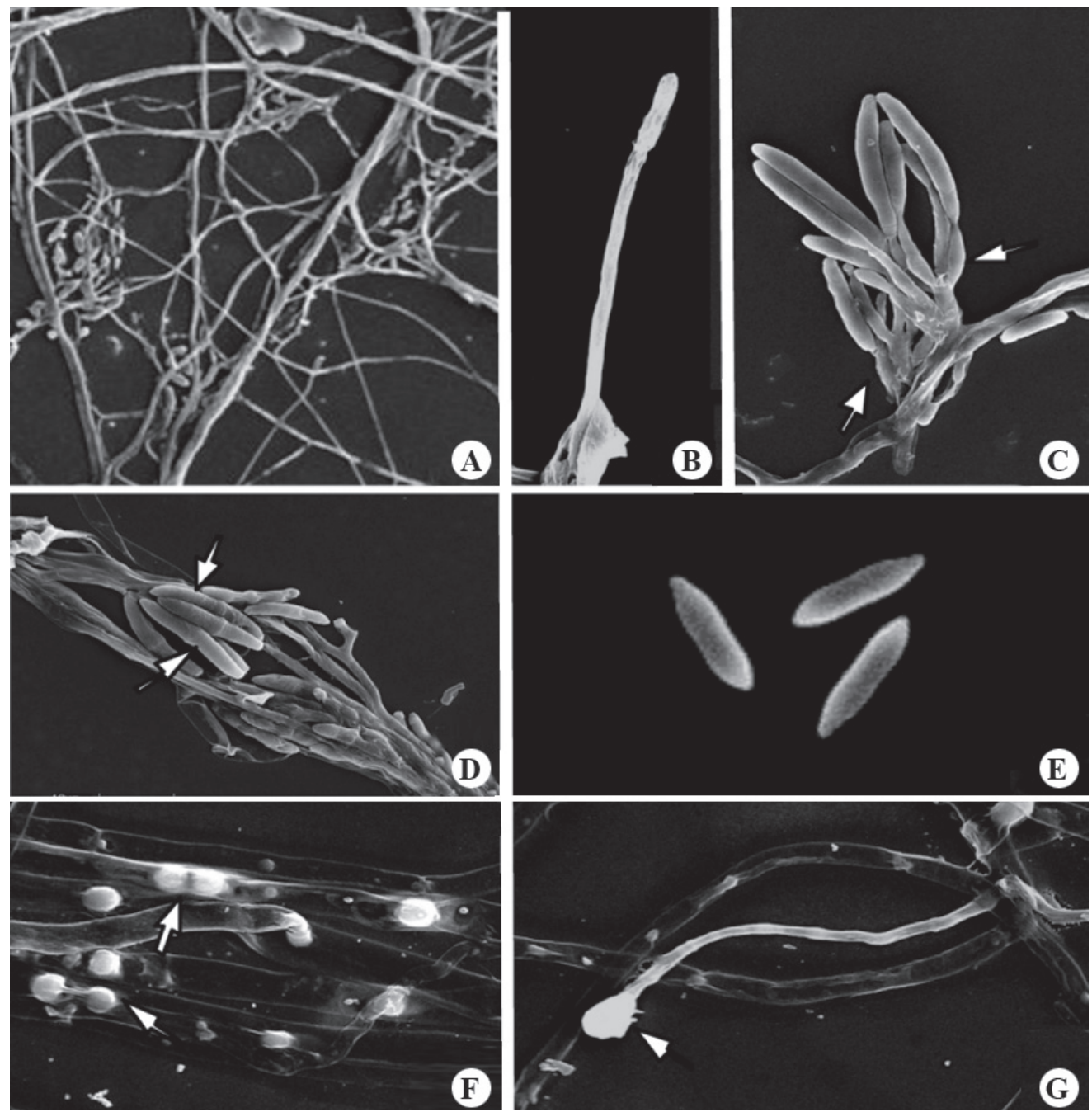

Figure 5. Scanning electron microscopy of ultrastructures of F usarium solani. (A) Mycelium (700X); (B) Phyalide (1500X); (C) Macroconidia in sporodochia (450X); (D) Macroconidia in sporodochia (400X); (E) Macroconidium (1500X); (F) Chlamydospore (1300X); (G) Chlamydospore (1600X).

Consequently the possibility can be ruled out that the damage developed in the inoculated plants was due to a nutritional deficit or another condition other than the virulence of the isolates determined as Fusarium spp. The results showed that there were more $F$. oxysporum types (48) than $F$. solani types (12) form isolates developed.

The isolates of $F$. solani produced symptoms of seedling drop, intense vascular wilt and mild vascular wilt. On the other hand, the isolates of $F$. oxysporum produced dwarfism and plants without symptoms (Figure 6), as well as the aforementioned symptoms. It is interesting to note that the latter species produced more variety of symptoms than $\operatorname{did} F$. solani, which could be related to the greater number of evaluated isolates. This reflects the genetic plasticity of $F$. oxysporum. According to the percentages provided, F. oxysporum presents greater virulence (Figure
6). This species also present a wider range of hosts, as Latorre (1995) demonstrated.

The wide variety of symptoms established for the two species of Fusarium were anamorphic forms and was present in inoculated calla plants. However, there are other species of Fusarium that are heterothallic and consequently can have sexual cycles. These are classified in the genus Calonectria, Nectria and Giberella (Kerenyi et al., 2004). As well, the genetic characteristics of each species and environmental conditions can favor the development and adaptation of the fungus, as pointed out by Gordon and Martyn (1997), and Wang and Jeffers (2002). Smith et al. (1992) recognize Nectria haematococca Berk. \& Broome as the teleomorphic state of $F$. solani. In general, it is difficult to determine if the degree of virulence of isolates of Fusarium spp. decreased 
Table 2. Characteristics of the microscopic structures of Fusarium solani and F. oxysporum.

\begin{tabular}{|c|c|c|}
\hline Parameters & Fusarium solani & Fusarium oxysporum \\
\hline Color of the colony (PDA) & $\begin{array}{l}\text { Light yellow, moist appearance, red with } \\
\text { cottony and orange brown mycelium, } \\
\text { with light brown exudate }\end{array}$ & $\begin{array}{l}\text { Light and dark violet, salmon- colored, } \\
\text { purplish brown, all with cottony } \\
\text { mycelium, without exudate }\end{array}$ \\
\hline Growth (PDA) & 4-5 days & $\begin{array}{l}4-5 \text { days } \\
\text { Extended ovals }(5-12 \times 2.2-3.5 \mu \mathrm{m})\end{array}$ \\
\hline Type of microconidias (AC) & $(8-16 \times 2-4 \mu \mathrm{m})$ & \\
\hline Type of macroconidias (AC) & $\begin{array}{l}\text { Abundant, cylindrical, dorsal and } \\
\text { ventral surface parallel, 3-5 septa (35-55 } \\
\text { x 4.5-6 } \mu \mathrm{m})\end{array}$ & $\begin{array}{l}\text { Abundant, sickle-shaped, } 3 \text { to } 5 \text { septa } \\
\text { with distinctive cellular foot } \\
(27-55 \times 3-5 \mu \mathrm{m})\end{array}$ \\
\hline Types of chlamydospore (AC) & Single or in pairs & Abundant, single or in pairs \\
\hline Type of phyalide (AC) & Long and thin, approx. $100 \mu \mathrm{m}$ or more. & $\begin{array}{l}\text { Short robust monophyalides in straight or } \\
\text { vertical angles }<20 \mu \mathrm{m} \text {. }\end{array}$ \\
\hline
\end{tabular}

PDA: potato dextrose agar (Tuite, 1969); CA: carnation agar (sterile carnation leaves on water agar).

after handling under laboratory conditions. If that happened, that is, loss of virulence because of continuous sub-cultures, it is probable that it would have occurred in mild degree. Nevertheless, demonstrating pathogenic activity and complying with Koch's postulates fulfill the purpose of this work, which was to associate an agent with pathology. Upon completing the tests, the plants with symptoms were removed from the climatic chambers, the tubers were incubated and the agent causing the symptoms was re-isolated in PDA.

The virulence of Fusarium spp. depends on the particular susceptibility of the host, which allows for the establishment of the infection in the plant. It is also important to point out that Fusarium spp. has several cellular and molecular attributes that together can confer different degrees of virulence. The combination of these virulence factors and host susceptibility contribute to the invasive development of Fusarium spp. in the plant (Nelson et al., 1994). Below is a brief consideration of each symptom developed in calla plants as a consequence of the inoculations with the evaluated strains of Fusarium after around 6 days of growth, which was sufficient time to carry out the tests.

Seedling damping off. Some $14 \%$ of the plants developed this symptom, with the seedlings dying in the first two weeks of planting after emergence. Similar results to those obtained in this study are described by Wang and Jeffers (2002), who inoculated strains of $F$. hostae in plants of Hyacinthus spp. and found that the most virulent strains produced necrosis and seedling damping off. There were no re-isolations; consequently the soil in the pots was tindalized, which ensured the symptoms developed were due to the inoculations.
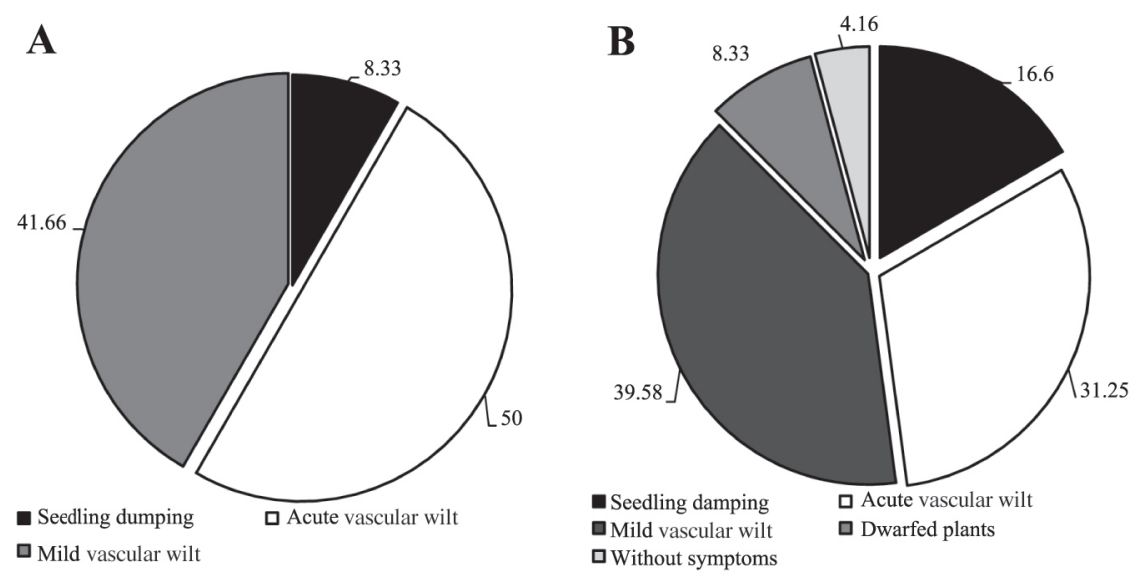

Figure 6. Distribution of symptoms (\%) developed by calla plants inoculated with Fusarium solani (A) and $F$. oxysporum (B). 
Dwarfism. The plants that developed dwarfism (height below $30 \mathrm{~cm}$ ) took longer to emerge than the rest and one month after emergence in the controls without inoculation. In addition to delayed development, these plants showed evidence of mild chlorosis by the end of the assay. The plants also had small thin leaves, which was evidence of poor development. Wang and Jeffers (2002) point out that strains of Fusarium spp. produce plants with depressed growth. Rose and Parker (2003) explain that one of the most important aspects of Fusarium spp. is that it affects the size of the plant, as was observed in this study, this being the one of the main symptoms in plants in the field and artificially inoculated plants. The only species responsible for this pathology was $F$. oxysporum, with only four isolates.

Vascular wilt. The plants that presented this symptom emerged in the first 2 weeks. After the first month they did not present any symptoms. The only difference was that they were 5 to $7 \mathrm{~cm}$ shorter than the controls. However, other plants were as tall as the controls. Beginning the second month of the assay, the plants began to develop chlorosis in the point of some leaves, which advanced to the interior of the leaves, turning them brown and wizenedlooking. At the same time, the stalks dried and finally the plant collapsed. The symptom of vascular wilt became more intense and attacked the other the stalks of the plants. By the end of the assay the plants were completely wilted. The intensity of these symptoms (Figure 6) could be because both species of Fusarium caused the damage later and different in nature from those of the isolates that produce seedling damping off and dwarfism, given that this group grows normally and slowly begins to become weaker. This syndrome, according to Agrios (1997), is a product of toxins released by this species that can advance through the vascular system, with the consequent occlusion of conductors, impeding the transfer of water and nutrients to the leaves, resulting in their drying out. It is known that species and forms of Fusarium spp. produce toxins that contribute to plant wilt in that it affects cell membrane permeability and interrupts cellular metabolism, which could explain the intensity of the wilting in this group of plants (Alexopoulos et al., 1996).

Mild vascular wilt. The emergence occurred in the first two weeks. In the first 3 months the plants did not show any symptoms. In the fourth month of development, the plants presented chlorosis in the leaf points, which advances to the interior of the leaf. This is accompanied by slight drying of the stalks. According to Rekah et al. (2000) and Ortoneda et al. (2004), F. oxysporum presents different effects on the same cultivar, which is because it has distinct forms. As well, according to Narasimhan et al. (2003), the pathogenicity can be related to the union between proteins and antimicrobial peptides of the host that protect the plant from the attack and invasion of a $F$. oxysporum.

Without symptoms. Only two isolates of Fusarium did not cause any symptoms in either the aerial or underground parts of the plants. Nevertheless, there were differences between the plants without symptoms and the controls in terms of height and stalk diameter. This factor could have been the product of having been cultivated in a laboratory and then conserved in PDA in a collection, given that the virulence of Fusarium spp. can decrease considerably or even be lost under these conditions (Armstrong and Armstrong, 1975). Rodrigues and Menezes (2005) indicate that Fusarium spp. can colonize root cortex without causing symptoms of the disease and survive in living tissue. As well, they the can exercise antagonism with pathogenic forms in the soil. According to this, it is possible to point out that the two evaluated isolates evaluated in this group of plants caused mild symptoms, which could be because they are two strong low virulence strains of Fusarium. It is also possible the results are due to intrinsic characteristics of the plant or to factors not considered in the objectives of this research.

Fusarium solani (teleomorph $N$. haematococca) is a species associated with many hosts. According to Smith et al (1992), F. solani sensu lato is found in the soil and can be the cause of seedling drop, basal rotting and stalk cankers in almost any species, as is the case of $F$. oxysporum and other species of this genus. On the other hand, F. oxysporum is present in the soil, some strains being pathogens of some hosts, but only in a small proportion. Some strains cause seedling death, necrosis and rotting. Nevertheless, the strains responsible for vascular wilt are the most important.

\section{CONCLUSIONS}

The colored callas inoculated with 60 isolates of Fusarium Link developed different symptoms; the most serious being the fall of seedlings, followed by dwarfism, acute vascular wilt, mild vascular wilt and finally plants without symptoms but with differences in height and stalk diameter.

The pathogenicity tests revealed two new pathogenic species for the cultivation in Chile of calla lily grown under greenhouse conditions.

$F$. oxysporum was found in greater quantity and with a higher degree of virulence, followed by $F$. solani to a lesser degree. As well, F. oxysporum induced dwarfism, which reflects a higher degree of virulence. 


\section{ACKNOWLEGEMENTS}

This research was carried out thanks to the support of the FONDEF Project DO3I 1140: "Formulaciones y estrategias para mejorar el biocontrol de enfermedades en cultivos de elevada importancia socioeconómica en Chile. Modelos Rhizoctonia solani en papas y Erwinia carotovora en calas" (Formulations and strategies to improve the biocontrol of diseases of high socioeconomic importance in Chile: Rhizoctonia solani model in potatoes and Erwinia carotovora in calla)

\section{RESUMEN}

Identificación de dos especies de Fusarium Link causantes de marchitez vascular en calas de colores (Zantedeschia aethiopica (L.) Spreng.) cultivadas bajo condiciones de invernadero en Chile. El cultivo de la cala de color (Zantedeschia aethiopica (L.) Spreng.) es un producto que está conquistando los mercados internacionales. Para su producción es de vital importancia mantener la sanidad en el cultivo durante su desarrollo, para obtener plantas de calidad que cumplan con los requerimientos exigidos por los mercados. El objetivo de esta investigación fue establecer el o los agentes etiológicos involucrados con la súbita aparición de síntomas de marchitez vascular en plantas de calas cultivadas bajo invernadero. Para esto se realizó una colección de cepas fúngicas a partir de muestras de plantas afectadas. Además, se realizaron pruebas de patogenicidad, observaciones microscópicas y de microscopía electrónica de barrido. Túberos sanos de cala fueron inoculados con cepas del género Fusarium Link. Éstos se desarrollaron durante 5 meses en una cámara climática, en donde manifestaron síntomas de caída de plántulas, enanismo, marchitez vascular intensa, marchitez vascular leve y plantas sin síntomas. Finalizado el ensayo se identificaron las cepas a nivel de especie, encontrando cerca de un 20\% de Fusarium solani (Mart.) Sacc. y un $80 \%$ de Fusarium oxysporum Schltdl., siendo este último más virulento. Los resultados obtenidos y las evidencias recolectadas muestran a estas dos especies fitopatógenas nuevas que afectan al cultivo de cala de color bajo condiciones de invernadero para Chile.

Palabras clave: Fusarium solani, Fusarium oxysporum, cala de color, Zantedeschia aethiopica.

\section{LITERATURE CITED}

Agrios, G. 1997. Plant pathology. $4^{\text {th }}$ ed. 635 p. Academic Press, San Diego, California, USA.
Alexopoulos, C., C. Mims, and M. Blackwell. 1996. Introductory mycology. $4^{\text {th }}$ ed. 869 p. John Wiley and Sons, New York, USA.

Armentrout, V.N. 1988. Population assessment of Fusarium spp. in soil. p. 13.1-13.4. In A.B.A.M. Baudoin (ed.) Laboratory exercises in plant pathology: An instructional kit. The American Phytopathological Society, St. Paul, Minnesota, USA.

Armstrong, M., and J. Armstrong. 1975. Reflections on the wilt Fusaria. Ann. Rev. Phytopathol. 13:95-103.

Booth, C. 1975. The present status of Fusarium taxonomy. Ann. Rev. Phytopathol. 13:83-93.

Ciampi, L., S. Radic, y E. Alvarez. 2006. Patología vegetal micológica. 266 p. Editorial Nuova Firenze, Valdivia, Chile.

Cook, R. 1993. Making greater use of introduced microorganisms for biological control of plant pathogens. Ann. Rev. Phytopathol. 31:53-80.

Cook, R., and K. Baker. 1989. The nature and practice of biological control of plant pathogens. $539 \mathrm{p}$. The American Phytopathological Society, St. Paul, Minnesota, USA.

Dhingra, O., and J. Sinclair. 2000. Basic plant pathology methods. 355 p. CRC Press, Boca Ratón, Florida, USA.

Gordon, T., and R. Martyn. 1997. The evolutionary biology of Fusarium oxysporum. Ann. Rev. Phytopathol. 35:111-128.

Hertogh, A., and M. Le Nard. 1993. The physiology of flower bulbs. 810 p. Elsevier Science, Amsterdam, The Netherlands.

Jacobs, F. 1997. Calla en maceta y calla para flor cortada, dos nuevas posibilidades para el mercado español. Available at http://www.ediho.es/horticom/tem-ar/ calla.html (accessed 1 November 2004).

Kerenyi, Z., A. Moretti, C. Waalwijk, B. Olah, and L. Hornok. 2004. Mating type sequences in asexually reproducing Fusarium species. Appl. Environ. Microbiol. 70:4419-4423.

Kunstmann, J. 2004. Determinación de subespecies de Erwinia carotovora (Dye) Hall como agentes causales de "pudrición blanda" en cala (Zantedeschia spp.). 103 p. Tesis Licenciado Agronomía. Universidad Austral de Chile, Facultad de Ciencias Agrarias, Valdivia, Chile.

Latorre, B. 1995. Enfermedades de las plantas cultivadas. 628 p. $4^{\text {a }}$ ed. Ediciones Universidad Católica de Chile, Santiago, Chile.

Narasimhan, M., H. Lee, B. Damsz, N. Singh, I. Ibeas, T. Matsumoto, et al. 2003. Overexpression of a cell wall glycoprotein in Fusarium oxysporum increases virulence and resistance to a plant PR-5 protein. Plant J. 36:390-400. 
Nelson, P., C. Dignani, and A. Elias. 1994. Taxonomy, biology and clinical aspects of Fusarium species. Clin. Microbiol. Rev. 7:479-504.

Ortoneda, M., J. Guarro, P. Madrid, Z. Caracuel, M. Roncero, E. Mayayo, and A. Di Pietro. 2004. Fusarium oxysporum as a multihost model for the genetic dissection of fungal virulence in plants and mammals. Infect. Immun. 72:1760-1765.

Rekah, Y., D. Shtienberg, and J. Katan. 2000. Disease development following infection of tomato in basil foliage by airborne conidia of the soilborne pathogens Fusarium oxysporum f. sp. radicis-lycopersicy and F. oxysporum f. sp. basili. Phytopathology 90:13221329.

Rodrigues, A., and M. Menezes. 2005. Identification and pathogenic characterization of endophytic Fusarium species from cowpea seeds. Mycopathologia 159:7985.

Rose, S., and M. Parker. 2003. Efficacy of biological and chemical treatments for control of Fusarium root and stem rot on greenhouse cucumber. Plant Dis. 87:14621470.

Salinger, J. 1994. Commercial flower growing. 629 p. Inkata Press, Sidney, Australia.
Smith, I., J. Dunez, R. Lelliott, D. Phillips, y S. Archer. 1992. Manual de las enfermedades de las plantas. 671 p. Ediciones Mundi Prensa, Madrid, España.

Snowdon, A.L. 1991. Post-harvest diseases and disorders of fruits and vegetables. $416 \mathrm{p}$. Volume 2: Vegetables. University of Cambridge. Wolfe Scientific Ltd., Aylesbury, England.

Tuite, J. 1969. Plant pathological methods, fungi and bacteria. 239 p. Burgess Publ. Co., Minneapolis, Minnesota, USA.

Von Arx, J. 1981. The genera of fungi sporulating in pure culture. 424 p. Gantner Verlag, Vaduz, Germany.

Wang, B., and S. Jeffers. 2002. Effects of cultural practices and temperature on Fusarium root and crown rot of container-grown hostas. Plant Dis. 86:225-231.

Wright, P. 1998. Pathogenicity of Erwinia carotovora subsp. carotovora, Fusarium solani and Rhizoctonia spp. to calla. New Zealand Institute for Crop \& Food Research Limited. Available at http://www.hortnet. co.nz/publications/nzpps/proceedings/98/posters.pdf (accessed 2 June 2004). 